\title{
Communicative Language Teaching in an EFL Context: Learners' Attitudes and Perceived Implementation
}

\author{
Sahail M. Asassfeh \\ English Department \& Department of Curriculum and Instruction, Hashemite University, Zarqa, Jordan \\ Email: suhail_habashneh@yahoo.com \\ Faisal M. Khwaileh \\ Department of Curriculum and Instruction, University of Jordan, Amman, Jordan \\ Email: khwaileh@ju.edu.jo \\ Yousef M. Al-Shaboul \\ English Department \& Department of Curriculum and Instruction, Hashemite University, Zarqa, Jordan \\ Email: yshbool@hu.edu.jo
}

Sabri S. Alshboul

English Department, Hashemite University, Zarqa, Jordan

Email: sabri@hu.edu.jo

\begin{abstract}
Communicative language teaching (CLT) applicability to English as a foreign language (EFL) contexts has recently been debated extensively. This study addressed 1525 Jordanian EFL school learners' attitudes and perceived implementation of traditional form-focused (FFI) instruction and communicative meaning-oriented instruction (MOI) of English. The data were collected using a 41-item questionnaire and analyzed using descriptive and referential statistics. Results showed that students' preferences associated with MOI were relatively higher. Too, whereas EFL instruction met learners' preferences associated with FFI, it rarely responded to learners' MOI needs. More precisely, despite some MOI practices, the gap between students' preferences and teaching practices associated with MOI was much wider than that between students' preferences and teaching practices associated with FFI. Female learners held relatively higher preference and reported significantly higher exposure to MOI. Compared to private-school learners, public-school learners held higher preference for and more involvement MOI. Low-proficiency learners reported higher preference to, and more practice of, FFI. These results were discussed, and recommendations were set accordingly.
\end{abstract}

Index Terms-EFL instruction, meaning-oriented instruction, form-focused instruction, communicative language teaching

\section{INTRODUCTION}

Due to the great potential communicative competence has played in the emergence of communicative language teaching (CLT) approaches and shaping of well-informed language pedagogies, it has remained a concept that arouses researchers' curiosity providing a framework that integrates language theory and teaching practice (Savignon, 1991). Rigorous theoretical and empirical research have made applied linguists and educators realize that communicatively competent language users need knowledge of the language and, more importantly, active use and evident ability to put this knowledge in authentic communicative events (Chung \& Huang, 2009). Notwithstanding this realization, English language educators, teachers, and learners, continue aspiring to fully grasp the concept of communicative competence, let alone putting it into practice. Instead, there is persistent ambiguity among both learners and teachers pertinent to what CLT is (Savignon, 2007).

CLT is a multi-perspectival approach that builds on several disciplines including linguistics, psychology, philosophy, sociology, and education. It focuses on carrying out and implementing methodologies that are capable of enhancing the learner's functional language ability through active involvement in authentic communicative (Savignon, 2007). Savignon asserts that what lies at the heart of CLT is the understanding that language learning is an educational and a political issue as well. The first step in determining such aspects as the teaching method and materials that match the goals of EFL instruction, accordingly, is the immediate context or setting in which EFL instruction is to take place. Given this understanding, CLT is best viewed as an approach, rather than a method, that maintains some level of consistency in the theoretical framework with a much wider room for individual interpretation and variation than most methods usually allow when it comes to decisions concerning design and procedure (Richards \& Rogers, 1986). 
One important distinctive feature of CLT is its emphasis on meaning-oriented instruction (MOI), a term that emerged in response to language teaching methods that emphasized the mastery of language forms (Hedge, 2000). Educators' increasing awareness that learners acquire a foreign language best when their attention is focused on the meaning communicated rather than on the linguistic form led to a lack of interest in such methods as grammar translation and audioingualism. Krashen and Terrell's (1983) natural approach, for example, stressed that if second language acquisition is sought, it is important that the teacher provides learners with sufficient comprehensible input and natural communication opportunities in a psychologically non-threatening environment. In line with this, Prabhu (1987) proposed that learning is at its best when the learner indulges in meaning-oriented activities such as information, reasoning, and opinion gap tasks. Today, meaning-oriented communicative language teaching methodology has the overarching principles of focus on real communication, providing learners with opportunities to try out what they know, tolerance of learners' errors as a healthy sign of progress in developing the communicative competence, integrating the different skills (i.e., listening, speaking, reading, and writing), and allowing students to discover grammar rules by themselves (Richards, 2006, p. 13). Meaning-oriented instruction, therefore, aims at developing the language learners' communicative competence through paying close attention to authentic language use, encouraging learner-learner and peer- peer negotiation of meaning, encouraging learners' risk taking, focus on fluency, which entails emphasis on language production rather than correctness, and assigning importance to learners' autonomy (Williams, 1995). On the other hand, it undermines the importance of form-focused instruction (FFI) characterized by accuracy, error correction, and explicit instruction of grammar rules (Baleghizadeh, 2010).

The aforementioned awareness that learning a language through mastering its grammar constitutes but one component of communicative competence has influenced language teaching pedagogy in the last few decades through shifting attention from form-focused teaching (FFI) toward meaning-oriented teaching (MOI). Whereas the first type concerns any teaching action, planned or supplementary, that is proposed to encourage the language learner to attend to linguistic form (Ellis, 2001), the latter acknowledges the interdependence of language and communication towards the goal of language teaching, namely developing the learner's communicative competence (Larsen-Freeman, 2000).

MOI emphasizes learning how to communicate in a language through ample interaction in that language, adopting authentic materials, providing the learner with an opportunity to focus on the language as well as on the learning process, enhancing the learners' personal experiences as integral components of the classroom learning, and linking both the classroom language learning and the off-classroom activities (Nunan, 1991). Parallel to such understanding, MOI is not limited to face-to-face communication, nor is it confound to oral communication; it applies to reading and writing as well as long as learners are involved in meaning expression, interpretation, and negotiation. It does not also aim to dictate specific procedures or a particular type of activities (Savignon, 2007). Additionally, unlike form-focused grammar-oriented instruction, MOI has at its heart developing students' communicative competence (Richards \& Rogers, 1986).

In general terms, findings from empirical research (e.g., Alkhayyat, 2009; Aubrey, 2010; Chung \& Huang, 2009; İnceçay \& İnceçay, 2009; Matsuura, Chiba, \& Hilderbrandt, 2001; Rao, 2002; Savignon \& Wang, 2003) on EFL learners' attitudes toward MOI in different EFL contexts have reported some contradictory findings, recommending, therefore, an integration of both communicative and non-communicative activities as beneficial for learners. For example, Rao (2002) explored thirty Chinese EFL undergraduates' perceptions of communicative and noncommunicative activities using quantitative and qualitative data. Participants reported favoring some communicative (e.g., student-student and student-teacher interaction, personal responses to students' exercises, and songs) and other non-communicative activities (e.g., audio-lingual drills, dictionary exercises, teacher's explanations of grammatical rules, error correction, and obedience to teacher's instruction). A reconciliation of both activity types was recommended accordingly.

Rao's study was duplicated by İnceçay and İnceçay (2009) on thirty Turkish EFL university students with results showing students' preference of both communicative (e.g., whole-class discussion, pair-work, and group-work) and non-communicative (e.g., error correction and audioligual drills) activities. The researchers thus recommended an alignment of both activity types. Both studies (i.e., Rao, 2002; İnceçay \& İnceçay, 2009) attribute students' preference of non-CLT activities to the norms and traditions inherent in the teaching methods students are used to.

Savignon and Wang (2003) investigated Taiwanese EFL learners' perceptions and attitudes pertinent to classroom practices representative of form-focused and meaning-based instruction. The instruction the learners reported receiving, it was found, did not meet their needs and wants.

Chung and Huang (2009) interviewed 24 Taiwanese senior high school learners to investigate their attitudes toward the classroom leaning experience focusing on CLT. Their results revealed that despite the efforts of the Ministry of Education to implement, and students' positive attitudes toward, CLT, language teaching stressed memorization, grammar, and translation to meet exam requirements. They also reported difficulty in integrating CLT with traditional teaching methods adopted for so long. The focus of English teaching practice, they suggested, should shift toward developing students' communicative competence.

In a study that investigated factors which contribute to 22 Japanese business EFL learners' willingness to communicate in different sized classroom (a one-on-one classroom, a small group classroom, and a large group classroom), Aubrey (2010) found that the CLT approach increased willingness to communicate when students had a 
positive attitude towards CLT. This shows that developing learners' attitudes toward CLT enhances their willingness to communicate in EFL classrooms.

Matsuura, Chiba, and Hilderbrandt (2001) explored the beliefs of 301 Japanese students and 82 Japanese college and university English teachers about CLT instruction. The researchers reported that Japanese students tended to consider functions, speaking, grammar, listening, cultural differences, reading, non-verbal cues, pronunciation, and writing as important for learning communicative English. Reading, writing, and grammar were not considered as important as speaking and listening. In terms of the reasons why English should be learned, the results revealed that the majority of students believed that it was necessary to respond to each other and interact with their teachers. It was also important for them to familiarize themselves with the Western-style learning strategies and communication styles. Only one third believed that teachers should focus on grammar. In terms of the instructional materials, students' preference of topics that reflect everyday life interaction and learning about social issues students preferred was not assigned a lower level of perceived importance by their teachers.

Alkhayyat (2009) explored the extent to which Jordanian EFL teachers are aware of some characteristics of CLT and their implementation level of these characteristics, using a questionnaire and classroom observation. The results revealed that the study participants "had good knowledge ... in different degrees" of the characteristics addressed (ibid, p. 399) despite the hindering obstacles EFL teachers had in CLT implementation. Significant differences were reported attributed to (a) the teaching experience, in favor of above-15-year-experience teachers and (b) gender, in favor of male teachers. Alkhayyat recommended conducting similar survey research in different parts of Jordan.

Since CLT was first introduced with the aim of engaging students in authentic communication to develop their communicative competence, those learners play a decisive role in determining the level of success CLT may achieve (Chung \& Huang, 2009). Understanding the attitudes, beliefs, assumptions, preferences, and needs of the next generation is inevitable if EFL instruction is really behind empowering students linguistically and culturally (Savignon, 2007). Clear understanding of learners' attitudes and perceptions of CLT as a widespread framework in shaping current definitions of the goals set for EFL teaching is quintessential to help learners attain these goals (Savignon \& Wang, 2003). Simultaneously, discrepancies between those learners' attitudes, on the one hand, and classroom practices and goals, have been shown to affect learning negatively (Savignon \& Wang, 2003). Moreover, scholars (Horwitz, 1987, 1988; Victori \& Lockhart, 1995; Matsumoto, 1996; Oxford \& Green, 1996; Wenden, 1998, cited in Sakui \& Gaies, 1999, p. 487) agree that an exploration of learners' attitudes "can lead to more effective in- and out-of-class languagelearning behaviors as well as greater self-knowledge and autonomy." Nonetheless, learners' attitudes toward and beliefs about communicative language teaching have not received the due attention especially since "most studies look at learner attitudes and beliefs bout language learning in general; few focus on learner attitudes and beliefs about instructional practices in particular" (cf. Savignon, 2007, p. 225). Also, they "have, in general, received less attention than teacher beliefs." (Loewen et al., 2009, p. 92). Thus, this study sets to investigate learners' attitudes as well as perceived practices of CLT implementation in Jordanian schools with the aim of identifying areas of challenge towards further improvement.

\section{THE SETTING: JORDAN}

Towards meeting the needs of more Jordanians wanting to develop their ability to communicate in English, the Ministry of Education has adopted new policies. Dominated by traditional approaches in the 1960s and a structural approach in the 1970s, EFL instruction in Jordan witnessed a shift in the mid 1980s toward official adoption of the CLT approach (Kailani, 1995) in a context where the two most commonly instructional pedagogies currently used are communicative language teaching and grammar-focused instruction (Al-Jamal, 2007). With the advent of the new millennium, teaching English has become mandatory since the first, instead of, fifth grade; EFL and Arabic instruction begin simultaneously in both public and private schools.

There are some similarities and differences between public and private schools in Jordan. Given the centralized educational system in Jordan, both school types are alike in terms of applying the mandates of the Ministry of Education manifest in using the same textbooks and subjection to the same supervisory system. Nonetheless, particularly with relevance to English education, private schools have, in addition to the English textbooks mandated by the government, a supplementary textbook that may vary from one school to another. More often than not, these supplementary textbooks require a relatively higher proficiency level for learners to meet their demands. Additionally, many private schools have resident supervisors for different school subjects, which is not available in public schools. The last difference lies in the socio-economic status of the learners. Since public education is provided free for learners until the end of the $10^{\text {th }}$ grade (the K-12 grade-sequence system in Jordan is similar to that of USA) and given the high cost of private education in relation to the citizens' income, it can be safely stated that most citizens who can afford the cost of private education prefer sending their children to private schools. Teachers' salaries, especially those who are experienced, are generally higher in private schools. Finally, in addition to Arabic and English, some private schools teach French, the second most commonly taught language after English, since the beginning of the $1^{\text {st }}$ grade.

RESEARCH QUESTIONS

In response to the research problem addressed, this study is geared by the following questions: 
1. What attitudes and perceived practices pertinent to FFI and MOI do Jordanian EFL learners hold? Is there any discrepancy between students' attitudes and perceived practice?

2. Is there any statistically significant difference (alpha=.05) in Jordanian EFL learners' attitudes and perceived instructional practice pertinent to FFI and MOI according to difference in gender, school type (public vs. private), grade level (basic vs. secondary), or proficiency level (low, intermediate, high)?

3. What beliefs do Jordanian learners hold pertinent to EFL instruction in general?

\section{METHOD}

\section{A. Participants}

The current study sample comprised randomly selected 1525 (714 female and 811 Male) EFL students enrolled in both public $(N=738)$ and private $(787)$ schools from two Jordanian cities. The sample represented both basic $(N=727)$ and secondary $(N=798)$ grades. Participants were subcategorized according to their proficiency level, as measured by their grades in the English language course in their first semester, into three groups: (a) low proficiency (those with a grade of lower than 59\%; $\mathrm{n}=323)$, (b) intermediate $(60-79 \% ; N=466)$, and high proficiency ( $80 \%$ and above, $N=733)$.

\section{B. Instrument}

To collect data for this study, a modified version of Savignon and Wang's (2003) questionnaire was used for two purposes. First, the questionnaire was comprehensive enough to the different domains associated with CLT instruction. Secondly, it is assumed in the current study that it would be easier to compare results when comparable versions of the study instruments are used across several EFL settings.

The original questionnaire, administered by those researchers in Chinese and translated to English, was administered in the current study in the Arabic language. Two modifications were made on the original questionnaire (see the Appendix). First, whereas in the original questionnaire "Responses were scored from 1 to 7 on a scale in the Likert format and the scores then converted to a scale from -3 to +3 for ease in interpretation", the current study used a fourpoint Likert scale format whereby $1=$ strongly disagree, $2=$ disagree, $3=$ agree, and $4=$ strongly agree. This was made to avoid any ambiguity that would have arisen in interpretation since the original 7-point format ranged between the two extreme values strongly disagree and strongly agree without labels showing what the values in between (2-6) correspond to. It would also help in avoiding negative values in the possible responses. The second modification concerned the number of items in the questionnaire. In the original questionnaire, students were asked about attitudes and practices associated with their Senior high school as well as their Junior high school. Since the items were the same under each school level, the current study avoided repetition of these items resulting in a lower number of items and, instead, had the school level as one of the independent variables. Moreover, whereas Savignon and Wong's (2003) study had the limitation of administering the questionnaire to populations of freshman university students who were asked to reflect post hoc on their secondary school EFL classroom experience, the current study targeted student populations who are currently school learners. Instead of reflecting post hoc on old experiences, the sample of this study was asked to reflect on and report current attitudes and beliefs.

Since the original questionnaire was in English, it was translated into Arabic. Translation accuracy was verified using back-translation. Validity of the questionnaire and appropriateness for the Jordanian setting were verified through presenting it to three professors with expertise in EFL/ESL instruction, two experienced English language supervisors and two English teachers. Reliability was ensured through distributing the questionnaire to a sample of 50 students. Cronbach alpha coefficient was calculated yielding the following values: form-focused classroom practice (.63), meaning-oriented classroom practice (.81), form-focused classroom attitudes (.71), meaning-oriented classroom attitudes (.75), form-focused classroom attitudes (.85), and meaning-oriented classroom attitudes (.83). Following contacting the target schools and obtaining the respondents' consent, the questionnaire was administered to students during their English-lesson time. The time allocated for students' filling out of the questionnaire was 25 minutes. Filledup questionnaires were collected for further analyses using SPSS. Analyses were carried out using both descriptive (mainly mean and standard deviation values) and referential statistics (t-tests and ANOVA).

\section{Results}

The first research question addressed students' preference pertinent to, and reported actual implementation of, formfocused and meaning-focused EFL instruction. It also attempted to explore any discrepancy between students' learning preferences and actual instructional practice. The results of descriptive statistics showed that the mean response of students' preferences associated with $\mathrm{MOI}(\mathrm{M}=3.13, \mathrm{SD}=.76)$ was higher than that associated with $\mathrm{FFI}(\mathrm{M}=2.58$. SD $=.63$ ). The mean difference, paired sample $t$-test revealed, was significant, $t(1524)=-24.86, p<.001$. Noticeably, the mean response on preferences associated with MOI ranged between 3.09 and 2.87 whereas on those associated with FFI ranged between 2.94 and 2.29 .

Students' highest preferences were associated with having teachers create an atmosphere that promotes using English in class $(\mathrm{M}=3.33, \mathrm{SD}=.84)$. They also wished teachers would allow them to make trial-and error attempts towards 
developing their ability to communicate in English $(\mathrm{M}=3.27, \mathrm{SD}=.84)$. Students also favored communication-based English teaching $(\mathrm{M}=3.09, \mathrm{SD}=.95)$ and having grammar explanations when necessary $(\mathrm{M}=2.87, \mathrm{SD}=.98)$.

Whereas these preferences are associated with MOI, those associated with FFI received lower mean responses. Thus, relatively lower mean responses were associated with preferring grammar-focused English teaching at school $(\mathrm{M}=2.62$, $\mathrm{SD}=1.07)$, spending much of the class time in explaining and practicing grammar rules $(\mathrm{M}=2.54, \mathrm{SD}=1.04)$, using Arabic most of the time in the classroom $(\mathrm{M}=2.52, \mathrm{SD}=1.09)$, and not having the chance to participate in the English class $(M=2.29, \mathrm{SD}=1.07)$. In other words, the students wished to have less explanation of grammatical rules, less use of Arabic by teachers, and more activities that would invite them to interact with peers in English.

In terms of teaching practice, students' mean responses pertinent to MOI $(\mathrm{M}=2.8481, \mathrm{SD}=.60)$ was higher than that associated with FFI $(\mathrm{M}=2.59, \mathrm{SD}=.53)$. These mean differences were, as the results of paired-sample $t$-test indicated, statistically significant, $t(1524)=-12.24, p<.001$. This indicates that teachers tended to apply MOI practices. The most frequently used practices by English teachers were allowing students trial-and-error attempts in their learning $(\mathrm{M}=$ 3.16, $\mathrm{SD}=.97)$ and adopting communication-based teaching $(\mathrm{M}=3.10, \mathrm{SD}=.89)$, which belong to MOI. These practices were followed by doing sentence drilling and repeating sentences after the teacher $(\mathrm{M}=3.00, \mathrm{SD}=.876)$, a purely FFI. Students also reported that teachers often created an atmosphere that would promote using English $(\mathrm{M}=2.98, \mathrm{SD}=1.04)$ On the other hand, students reported teachers did not often design activities that had students interact in English with peers $(\mathrm{M}=2.38, \mathrm{SD}=.98)$. Students seemed also not to agree that the language used in the classroom by their teachers was mostly Arabic $(\mathrm{M}=2.37, \mathrm{SD}=.93)$.

The above results indicate English teachers adopted MOI. However, it is important to see the extents to which teachers responded to students' preferences related to the two types of instruction. Descriptive statistics showed that the total mean response of students' preferences $(\mathrm{M}=2.58, \mathrm{SD}=.63)$ and perceived instructional practices $(\mathrm{M}=2.59, \mathrm{SD}$ $=.53$ ) pertinent to form-focused instruction were comparable, i.e. the difference was not statistically significant. However, the discrepancy between those students' preferences about meaning-focused instruction $(\mathrm{M}=3.13, \mathrm{SD}=.76)$ and their perceived practice $(\mathrm{M}=2.84, \mathrm{SD}=.60)$ was statistically significant, $\mathrm{t}(1524)=-12.997, p<.001$. These results indicate that whereas EFL teachers met students' preferences associated with FFI, they rarely responded to students' MOI needs. More precisely, despite using some MOI practices, the gap between students' preferences and teaching practices associated with MOI was much wider than the gap between students' preferences and teaching practices associated with FFI.

Results of Question Two:

The second question addressed the impact of students' gender, school type (public vs. private), grade level (basic vs. secondary), and proficiency level (low, intermediate, high) on their preference and perceived instructional practice pertinent to MOI and FFI. Following are the results.

\section{A. Gender Effect}

To begin with, the impact of gender was examined using $t$-test. The results showed that there was a significant effect for gender associated only with the perceived practice of MOI, $t(1523)=2.22, p<.02$, in favor of female $(\mathrm{M}=2.89$, SD $=.61)$ compared to male $(\mathrm{M}=2.81, \mathrm{SD}=.02)$ students. This indicates that female students reported more emphasis from their teachers on MOI. Additionally, though the difference was not significant, females $(\mathrm{M}=3.17, \mathrm{SD}=.76)$ reported relatively higher preference to $\mathrm{MOI}$ than males $(\mathrm{M}=3.10, \mathrm{SD}=.76)$.

\section{B. School Type Effect}

To examine whether school type (public or private) had any impact on students' attitudes or perceived practices associated with the two types of instruction, t-test was used. The results showed statistically significant difference $($ alpha $=.05), t(1525)=-6.88, p<.0001$, associated with the perceived practice of FFI only. Public-school learners $(\mathrm{M}=2.69, \mathrm{SD}=.48)$, compared to their partners in private schools $(\mathrm{M}=2.50, \mathrm{SD}=.55)$, reported significantly higher adoption of FFI than MOI in their English education. This significant difference was reflected in the relative, nonsignificant difference associated with $\mathrm{MOI}$ in favor of private-school learners $(\mathrm{M}=2.87, \mathrm{SD}=.62)$ compared to publicschool learners $(\mathrm{M}=2.82, \mathrm{SD}=.58)$. On the other hand, it is interesting to see that whereas students' perceived practice associated with FFI differed statistically, this significant difference was not mirrored in those learners' attitudes associated with FFI, whether they belonged to private $(\mathrm{M}=2.58, \mathrm{SD}=.65)$ or public schools $(\mathrm{M}=2.57, \mathrm{SD}=.61)$.

\section{Grade Level Effect}

The impact of students' grade levels (basic vs. secondary) on their attitudes toward, and perceived practice pertinent to, CLT was tested using $t$-test. The results showed a statistically significant difference (alpha=.05) in both FFI practices, $t(1523)=3.383, p<.001$, and attitudes, $t(1523)=-6.244, p<.001$. Basic school graders, it was noticed, reported significantly higher emphasis by their teachers on form-focused instruction $(\mathrm{M}=2.65, \mathrm{SD}=.52)$ than that reported by secondary school graders $(\mathrm{M}=2.55, \mathrm{SD}=.53)$. However, secondary graders $(\mathrm{M}=2.68, \mathrm{SD}=.61)$ had significantly higher preference for FFI than had basic school graders $(\mathrm{M}=2.47, \mathrm{SD}=.64)$.

\section{Proficiency Level Effect}


Possible differences in students' attitudes and perceived instructional practices according to their proficiency levels were examined using One Way Analysis of Variance (ANOVA). The results, Table 1, revealed a statistically significant difference between the student groups at the level of both attitudes and perceived instructional practices associated with each of the two types of instruction. Thus, a significant difference, $F(2,1519)=25.21, p=.001$ was associated with form-focused practices, $F(2,1519)=4.27, p=.014$, meaning-oriented practice, $F(2,1519)=9.24, p=.001$, formfocused attitudes as well as with meaning-oriented attitudes, $F(2,1519)=10.03, p=.001$. Follow up the source of difference, using Tukey HSD, revealed that the low proficiency group was consistently involved in causing the difference. Thus, they reported significantly higher exposure to form-focused instruction $(\mathrm{M}=2.72, \mathrm{SD}=.45)$ than the intermediate $(\mathrm{M}=2.66, \mathrm{SD}=.45)$ and high-proficiency $(\mathrm{M}=2.50, \mathrm{SD}=.58)$ groups. Additionally, they reported exposure to less meaning-oriented instruction $(\mathrm{M}=2.78, \mathrm{SD}=.61)$ than did the intermediate $(\mathrm{M}=2.91, \mathrm{SD}=.56)$ and high proficiency $(\mathrm{M}=2.84, \mathrm{SD}=.62)$ groups. With regard to their attitudes toward form-focused instruction, they had higher perceptions $(\mathrm{M}=2.68, \mathrm{SD}=.56)$ than both of the intermediate $(\mathrm{M}=2.61, \mathrm{SD}=.60)$ and high proficiency $(\mathrm{M}=2.51$, $\mathrm{SD}=.67)$ groups. Their mean response pertinent to their attitudes toward meaning-oriented instruction $(\mathrm{M}=3.06$, $\mathrm{SD}=.64)$ were significantly higher than those held by either of the intermediate $(\mathrm{M}=3.04, \mathrm{SD}=.56)$ or the high proficiency $(\mathrm{M}=3.22, \mathrm{SD}=.90)$ groups.

TABLE 1.

ANOVA FOR FFI AND MOI AND PROFICIENCY LEVELS

\begin{tabular}{|c|c|c|c|c|c|c|}
\hline & & Sum of Squares & df & Mean Square & $\mathrm{F}$ & Sig. \\
\hline \multirow{3}{*}{ FFI Practice } & Between Groups & 13.747 & 2 & 6.873 & \multirow[t]{3}{*}{25.214} & \multirow{3}{*}{$.000 *$} \\
\hline & Within Groups & 414.088 & 1519 & .273 & & \\
\hline & Total & 427.834 & 1521 & & & \\
\hline \multirow[t]{3}{*}{ MOI Practice } & Between Groups & 3.099 & 2 & 1.549 & \multirow[t]{3}{*}{4.269} & \multirow[t]{3}{*}{$.014 *$} \\
\hline & Within Groups & 551.344 & 1519 & .363 & & \\
\hline & Total & 554.443 & 1521 & & & \\
\hline \multirow[t]{3}{*}{ FFI Attitudes } & Between Groups & 7.398 & 2 & 3.699 & \multirow[t]{3}{*}{9.240} & \multirow[t]{3}{*}{$.000 *$} \\
\hline & Within Groups & 608.066 & 1519 & .400 & & \\
\hline & Total & 615.464 & 1521 & & & \\
\hline \multirow[t]{3}{*}{ MOI Attitudes } & Between Groups & 11.598 & 2 & 5.799 & \multirow[t]{3}{*}{10.029} & \multirow[t]{3}{*}{$.000^{*}$} \\
\hline & Within Groups & 878.277 & 1519 & .578 & & \\
\hline & Total & 889.874 & 1521 & & & \\
\hline
\end{tabular}

* Significant at the .05 level.

Students' attitudes pertinent to EFL instruction in general

The third question addressed Jordanian students' beliefs pertinent to EFL instruction in general. The results showed that the highest mean value $(M=3.36, S D=.85)$ was associated with students' belief that it is important to have teachers correct their errors in class. Students also strongly believed that the formal study of grammar is essential to eventual mastery of the target language $(M=3.33, S D=.85)$. Additionally, they reported favoring a classroom atmosphere that encourages class or group interaction $(M=3.26, S D=.89)$. Making trial-and-error attempts to communicate in English helped them to learn English $(M=3.25, S D=.91)$, they reported. Next, according to preference order, came students' expression of their wish to speak native-like English $(M=3.25, S D=.922)$. They also believed English is useful in getting a good job $(M=3.21, S D=.92)$. Furthermore, students reported convenient support of having English education begin since the kindergarten $(M=3.19, S D=.95)$. Of equal importance, students believed, English education should begin in kindergarten education. Students further had similar responses to the beliefs that learning English is learning to use it and that the practice of English in real-life or real-life like situations is important towards this end $(\mathrm{M}=3.16, \mathrm{SD}=90)$.

On the other hand, the lowest mean value was associated with the belief that speaking English in the classroom is not essential for learning it. $(M=2.35, S D=1.16)$, which indicates that students believed interaction is quintessential in the language learning process. They also expressed a low level of agreement with the idea that errors are to be avoided in the process of learning English $(M=2.77, S D=1.00)$. Relative disagreement was also associated with the belief that practicing grammatical patterns is more important than practicing English interactively in the classroom $(M=2.80$, $S D=1.08)$. Students reported relative higher agreement to the beliefs that good language learners are usually not only intelligent. $(M=2.87, S D=1.06)$ but are also likely to have good grades in other subjects $(M=2.89, S D=1.02)$.

\section{DISCUSSION}

The results of descriptive statistics concerning students' preference pertinent to, and perceived implementation of, FFI and MOI and possible discrepancies between students' learning preferences and actual instructional practice showed that students' preferences associated with MOI were significantly higher than those associated with FFI. These results indicate clearly that there is a tendency among Jordanian students toward developing their communicative competence. This trend may reflect the increasing awareness among Jordanian learners that they need not only to understand but also communicate English so that they can improve their country in terms of economy, cross-cultural communication, and international relations (Bani Abdo \& Breen, 2010). It also reflects tendency towards effective language use compared to language analysis. These results invite teachers to compensate for insufficient English-based communication outside the language classroom (Mourtaga, 2006) through creating a non-threatening, lively classroom atmosphere that 
promotes English use and allows learners to make trial-and error attempts towards developing their communicative ability. Simultaneously, the type of language classroom instruction learners are seeking is one that is characterized by avoidance of grammar-focused English teaching, over-emphasis on grammar rule explanations, and over-reliance on Arabic in absence of rich participation and interaction with the teacher and classmates.

Students' perceived teaching practices are indicative of a shift from FFI towards MOI in the teaching of EFL. Despite the findings of other studies (e.g., Al-Wreikat \& Bin Abdullah, 2010) suggesting that EFL teachers' performance in general has not benefited a lot from the in-service teacher training programs aimed at equipping those teachers with good and effective techniques, others (e.g., Al-Wreikat \& Bin Abdullah, 2011) suggest that those in-service programs emphasize the importance of communicative language teaching. These in-service training programs, with the time and effort allocated for CLT, might be a reason behind the shift towards MOI perceived by the participants in the current study. However, EFL instruction still inherits some traditional FFI practices manifest in sentence drilling and sentences repetition after the teacher, lack of peer-peer interaction activities, and use of Arabic. These practices are not only strongly interrelated but can also be symptomatic of adopting traditional EFL instructional methodology. To explain, research findings (e.g., Al-Hadrami, 2008; Al-Shidhani, 2009) suggest that Arab EFL teachers resort to Arabic in the English classroom in explaining grammatical rules as well as in introducing new vocabulary items. Ironically, explaining grammatical rules and introducing new vocabulary items should presumably invite teachers to stick to CLT. As long as EFL teachers avoid introducing meanings of new vocabulary in the target language, they are unintentionally contributing to the suffering their students experience. Moreover, CLT recommends that avoiding explicit explanation of grammar rules in favor of English-based meaningful communication. The legitimate pedagogical question therefore is: when will EFL teachers assume their learners can handle language learning tasks if meanings are introduced in Arabic and grammar is taught explicitly and on what ground will this assumption stand? This question is echoed by AlShidhani (2009) who wonders how EFL teachers arrive at conclusions regarding learners' preferences and the impact such conclusions have on their instructional practice.

Al-Jamal (2007) found that Jordanian EFL school learners are aware of their weaknesses and inadequate competences they have developed, making their language learning experience dissatisfactory. Whereas their reported preferences show clearly their interest in English classroom participation and effective use of English as a medium for self-expression and negotiating meaning, the prevalent classroom techniques hardly leave a room for them to avoid passivity, ignorance of learning strategies, and dependence on the language teacher. Almost 79\% of her participants, she reported, suggested a direct correlation between their learning product and their teachers' adopted teaching methods, and around $74 \%$ believed that there is a better way of introducing English to them. The results of this study support her finding that almost $93 \%$ of Jordanian EFL school learners call for the introduction and adoption of innovative teaching methods. A lack of congruence between learners' preferences and actual implemented instructional practice is likely to de-motivate learners, leading to frustration. The results of this study suggest that whereas the margin between students' preferences and teachers' practices associated with FFI is minimal, EFL instruction in Jordan hardly meets students' preferences associated with MOI. What is needed, given these results, could probably be the direction, rather than the effort made by the educators, towards EFL methodology improvement in Jordan. Redirecting those educators' efforts toward MOI is quite urgent.

Preference and perceived instructional practices of MOI and FFI and learners' gender, school type, grade level, and proficiency level

\section{A. Gender}

The results of this study showed that gender had a significant effect associated with students' perceived practice of MOI in favor of females, who reported receiving more MOI, toward which they also held relatively higher preference than males. Several studies (e.g., (AlFaqara, 2010; Hashemi, 2011; Newman et al., 2008; Sunderland, 1992; Xin, 2008) have suggested a gender difference in more than one aspect pertinent to language learners in favor of females, which might help in interpreting these results. Xin (2008) for example reported that female Chinese EFL learners surpassed male students in their internal motivation to learn English; thus, they were more interested in learning English and less interrupted by external factors in their language learning experience. Siebert (2003) further reported that whereas males were more optimistic about their language learning ability, compared to only $23 \%$ of females, $47 \%$ of males agreed or strongly agreed that grammar is the most important component in foreign language learning. Other researchers (AlShaboul, Asassfeh, \& Alshboul, 2010; Bacon \& Finnemann, 1992; Hashemi, 2011; Sunderland, 1992) found that females are also more language strategy users. Willing (1988) found that both male and female adult immigrants in Australia preferred to learn many new words by seeing them and talking to friends in English; however, females had significantly higher preference. AlFaqara (2010) also reported that male students made more transfer errors in expressing English negation than did females. Other scholars, according to Sunderland (1992) have "showed sex differences in authentic language use and in searching for and communicating meaning" (p. 88).

In addition to these findings, one factor that seems to have received little attention though might help at least partially in the interpretation of females' increasing interest in education in general and in language learning in particular whether in Jordan or in other countries that have undergone similar conditions is the context in which EFL resides. That the educational system does not constitute an island, thus, does not function independently of other sectors, the social, political, and economic reform some developing countries witness in terms of the social roles associated with gender 
might have a say in this. According to a recent report (Hendessi, 2007, p. 7), women's employment is still a new ingredient of the Jordanian society; thus, despite the fact that Jordan has achieved the highest literacy rates for females in MENA countries, it has not yet broken "the taboo of women working outside home." Still, No less than half of the (15-year old and above) females are housewives thus are not participating in the labor force, with young women "more susceptible to unemployment and long-term inactivity, widening the gender gap and depriving society of their capabilities and qualifications (Kanaan \& Hanania, 2009, p. 156). This problem is neither recognized in policy circles nor is it "likely to reverse itself any time soon" (Miles, 2002, p. 416). The increasing awareness spreading among females could have probably led to improving their interest in joining the workforce outside home. Given this scenario, it becomes clear that whereas seeking a good job is important for both males and females, securing it can be more challenging for females, which is likely to demand obtaining an academic degree and, especially in an Englishized world, an adequate level of proficiency in English becomes quite necessary.

\section{B. School Type}

With regard to the impact of school type on learners' attitudes and perceived practice of FFI and MOI, the results of this study showed that FFI implementation was reportedly significantly higher in public schools. Simultaneously, whereas both student groups differed minimally in their attitudes pertinent to FFI, the difference was much higher with regard to MOI. These results suggest that private schools are moving fast towards MOI practice. One factor behind this difference is possibly the EFL teacher's attitude. For example, Abu Qbeita (n. d.) found that private-kindergarten EFL teachers held more positive beliefs about English education than public-kindergarten fellows, a difference she attributed to the knowledge-base, positive attitudes about English learning, and the suitable environment for EFL instruction provided in private kindergartens. Al-Hazaymeh (1994) also found that second secondary graders at private schools in Irbid, Jordan, encountered significantly less problems in dealing with English verb tenses. These results suggest that in both attitudinal and language competence, private-school teachers and learners are more advantaged.

\section{Grade Level}

Whereas both student groups favored communicative language teaching, the results related to the effect of learners' grade levels on attitudes and perceived practice of MOI and FFI indicated that secondary graders held significantly higher positive attitudes associated with FFI. There are two plausible interpretations for these results. The first relates to the way assessment is conducted in the Jordanian educational system. It is undoubtedly true that whatever communicatively competent they are, their grades on the Tawjihi exam constitute the only decisive factor in determining what specialty they can take at the university level. Since the Tawjihi is "still not designed to measure critical or independent thinking or to test students' aptitudes for different courses of study within the higher education system" (Kanaan \& Hanania, 2009, p. 150), Secondary graders may find themselves obliged to prepare themselves through text-based form-focused instruction. The second interpretation is based on a psycholinguistic ground. Yi (n.d.) suggests that plateau of learning, where there is effort without perceptible progress, is in effect when the learner during the early stages of learning can make direct use of what is learned through imitation, memorization and rote-learning of what the teacher and the textbooks introduce. The direct use and the novel linguistic input are motivating factors. As the EFL learner proceeds in the language learning experience, taking in new input becomes more challenging, leading to anxiety since the learners' expectations to master the language soon and to use it effectively for communicative purposes prove to be unrealistic. This in turn leads to anxiety and a low motivation. As the learner tries again, s/he goes through the same cycle, which may explain why, even after years of language learning, EFL learners feel they know the language but cannot develop the competence that enables them to use it as a medium of communication (ibid). Brought to the context of the current study, Secondary graders' preference to FFI might be the results of having had experienced attempts to develop the communicative competence, yet found it challenging; thus they resorted to FFI. Basic graders, on the other hand, are still motivated with the hope of conversing with others using English, leading to a higher preference to MOI.

\section{Proficiency Level Effect}

Compared to intermediate and high-proficiency groups, low-proficiency learners held significantly higher preference of FFI and reported significantly higher exposure to this type of instruction, which suggest an association between the proficiency level and students' preferences of FFI. These results can be interpreted in two ways. First, it can be argued that students who were taught using the MOI are the ones who had higher proficiency levels. That is, the higher proficiency level is an outcome of MOI. Additionally, it can be argued that students who have a higher proficiency level are the ones who are more aware of the importance of MOI, thus they report a higher preference for it and are, therefore, more able to identify the instructional practices that fall within its framework.

Students' beliefs pertinent to EFL instruction in general

A look at students' general beliefs about EFL learning suggests that whereas they are still caught with traditional EFL instruction orientations, they would actually prefer a communication-oriented approach. Thus, students' beliefs reflect a blend of both FFI and MOI with a clear inclination toward CLT. Whereas previous research findings (e.g., Al-Jamal, 2007) suggest that EFL teachers in Jordan agree that a combination of both grammar-based traditional instruction and communicative EFL instruction can best suit Jordanian EFL learners for learner-related variables such as motivation 
and English proficiency level, the results of this study seem to suggest that those teachers' assumptions about learners are not as accurate as those teachers assume.

According to students' perceptions in this study, whereas EFL Jordanian learners still believe teachers' correction of learners' errors is necessary, and mastery of English can hardly be obtained in absence of explicit grammar instruction, aspects that clearly lean toward a traditional learning philosophy, they express strong positive beliefs about CLT. For example, this study participants believed in the importance of sufficient English classroom interaction be it in the form of peer-peer interaction, group interaction, or whole- class interaction. They also held strong positive beliefs about the language itself and the importance of learning it. They also believed English interaction is quintessential towards developing language and communication competence. Learners' attitudinal factors, given these results, do not seem to be as impeding for CLT implementation in EFL contexts as it has generally been portrayed.

Errors, according to students' beliefs are part of the learning experience, which should invite EFL teachers to have and show more tolerance with these errors. Brought to the context of second language acquisition, these results suggest that Jordanian EFL learners feel a need for developing their fluency, rather than accuracy. Even though these two terms are to be viewed as complementary, and even though EFL instruction cannot claim addressing one in absence of the other, it is true that in actual teaching correctness is emphasized by traditional teaching when fluency is a characteristic of CLT.

Moreover, Jordanian EFL learners seem to associate the learning experience of English with an increased ability in using it instead of analyzing it. Learners' recommendation of starting English instruction as early as the beginning of $\mathrm{KG}$ education reflects their awareness of its importance as well as it might reflect their implicit expression of not having had the chance to develop their own communicative competence in the manner they wish.

\section{CONCLUSION}

Understanding learners' beliefs is quintessential to ensure that they receive the quality education of preference to them. Their views of which communicative aspects are necessary in actual instructional practices should guide the pedagogical decisions associated with their learning. One limitation in this study is that learner responses were not cross-validated through, for example, comparing them with teachers' beliefs, especially with regard to the actual implementation of MOI. This is strongly associated with the accuracy of learner reported attitudes and beliefs. Nonetheless, the findings of this study provide educators with insights into how learners view their EFL learning experience.

This study concludes that EFL instruction in Jordan has not gone that far in meeting learners' needs and wants pertinent to MOI instruction compared to meeting their beliefs pertinent to FFI. Savignon and Wang (2003, p. 240) note that "Taiwanese learners may be typical of learners in other EFL contexts in that they are very good at explaining the rules of English but are often unable to use English for communication." In support to what Savignon and Wang describe, it is the researchers' observation in the current study that even English-major undergraduates in the EFL context frequently complain when assigned a writing task or a listening comprehension activity that they had never been exposed to such type of activities during their years of school language learning.

Given this scenario, one way EFL instruction can be more responsive to learners' wants and more beneficial for their future is by seeking reconciliation between addressing language and language aboutness, with the latter term suggested in this study to denote aspects that are related to what is taught about language (e. g., language analysis, meta-language, and grammar). The introduction of this distinction is intended to raise educators' awareness and sensitivity towards addressing the language itself and its use, rather than describing its grammar and rules. Since language is a means of communication, a functional approach in teaching it is essential, especially since not all EFL school learners are presumed to take English as their major of study. Teachers, in line with this understanding, should make a distinction between the teaching methodologies of preference to them compared to those favored by their learners. Additionally, since instruction is a systematic, purposeful process, EFL teachers are also invited to teach what is likely to be beneficial for the future of their learners rather than what the teachers like to, or can, teach. It should no longer be allowed for learners to take a passive role in language learning if they are to meet the challenge of developing an adequate level of communicative competence. EFL learners' already developed positive beliefs about MOI can be enhanced through an alignment among textbook content, teaching methodology, and assessment strategies.

The results of this study have revealed that male EFL learners are less enthusiastic about MOI than females. Regular talks by EFL teachers on the importance of developing learners' communicative competence and the challenges of today's workplace may encourage such learners to have more enthusiasm about their language learning.

Despite the huge discrepancy in number between public and private schools in favor of the latter implying serving a wider learner population, the quality of language education in terms of both learner attitudes and perceived instructional practice suggest that private schools may offer good lessons to public ones. Further investigation of the differences between both can bring benefit to public schools. Moreover, the preference for FFI by secondary graders is indicative of an exam-oriented instruction. Probably the results could have been different had there been a new, different assessment policy. Finally, the strong association between proficiency level and instruction type preferences is inviting for further research. 


\section{ACKNOWLEDGEMENT}

The authors extend their deepest gratitude to the participants of the study and all those who helped in the different phases of carrying out the work.

\section{REFERENCES}

[1] Abu Qbeita, A. (no date). Kindergarten teachers' beliefs about teaching English in Jordan. http://www.najah.edu/page/3487 (accessed 27/3/2011).

[2] AlFaqara, W. (2010). The influence of colloquial Jordanian Arabic upon learning English negation by Jordanian EFL school students. Journal of Education and Sociology, 3, 53-57.

[3] Al-Hadhrami, A. (2008). The role of the L1 in Grade 5 EFL classrooms. In S. Borg (ed.). Investigating English language teaching and learning in Oman (pp. 19-27). Muscat: Ministry of Education, Oman.

[4] Al-Hazaymeh, Y. (1994). An analysis of the errors made by Jordanian Second Secondary students in learning English verb tenses. MA thesis, Yarmouk University.

[5] Al-Jamal, D. (2007). English teaching and learning experiences in Jordan: Attitudes and views. Umm Al-Qura University Journal of Educational \& Social Sciences \& Humanities 19.1, 29-55.

[6] Alkhayyat, A. (2009). Measuring EFL teachers' knowledge of communicative language teaching approach and their practices in the Jordanian public schools. Jordan Journal of Educational Sciences 5.4, 399-415.

[7] Al-Shaboul, Y. Asassfeh, S., \& S. Alshboul. (2010). Jordanian students learning English: Strategy deployment. The Buckingham Journal of Language and Linguistics 3, 101-120.

[8] Al-Shidhani, A. (2009). Teachers' beliefs about using Arabic in the English classroom. In S. Borg (Ed.), Researching English language teaching and teacher development in Oman (pp. 184-191). Muscat: Ministry of Education, Oman.

[9] Al-Wreikat, Y. A. \& M. K. Bin Abdullah. (2010). An evaluation of Jordanian EFL teachers' in-service training courses teaching techniques effectiveness. English Language Teaching 3.4, 18-27.

[10] Al-Wreikat, Y. A. \& M. K. Bin Abdullah. (2011). Effectiveness of teaching approaches of in-service training courses for EFL teachers in Jordanian schools. English Language Teaching 4.1, 190-196.

[11] Aubrey, S. (2010). Influences on Japanese students' willingness to communicate across three different sized EFL classes. MA Thesis. The University of Auckland. www.asian-efl-journal.com/Thesis/Thesis-Aubrey.pdf (accessed 13/2/ 2011).

[12] Bacon, S. \& M. Finnemann. (1992). Sex differences in self-reported beliefs about language learning and authentic oral and written input. Language Learning 42 .4, 471-495.

[13] Baleghizadeh, S. (2010). Focus on form in an EFL communicative classroom. Novitas Royal (Research on Youth and Language) 4.1, 119-128.

[14] Bani Abdo, I. \& G. Breen. (2010). Teaching EFL to Jordanian students: New strategies for enhancing English acquisition in a distinct Middle Eastern student population. Creative Education 1, 39-50.

[15] Chung, I. F. \& Y. C. Huang. (2009). The implementation of communicative language teaching: An investigation of students' viewpoints. The Asia-Pacific Education Researcher 18.1, 67-78.

[16] Hashemi, M. (2011). The impact of gender on language learning strategies of Iranian EFL learners. International Journal of Academic Research 3.2, 280-285.

[17] Hedge, T. (2000). Teaching and learning in the language classroom. Oxford: Oxford University Press.

[18] Hendessi, M. (2007). Jordan gender assessment. USAID Report by Sustainable Achievement of Business Expansion and Quality (SABEQ). http://www.sabeq-jordan.org/SABEQ_Files/633135301657855552.pdf (accessed 17/3/2011).

[19] İnceçay, G., \& V. İnceçay. (2009). Turkish university students' perceptions of communicative and non-communicative activities in EFL classroom. Procedia Social and Behavioral Sciences 1, 618-622.

[20] Kailani, T. Z. (1995). A synthesized pedagogical methodology for English classroom interactions, IRAL 33.4, 333-344.

[21] Kanaan, T. \& M. Hanania. (2009). The Disconnect between Education, Job Growth, and Employment in Jordan. In N. Dhillon and T. Yousef (Eds.), Generation in waiting: The unfulfilled promise of young people in the Middle East (pp.142-165). Brookings Institution Press.

[22] Krashen, S., \& T. Terrell. (1983). The natural approach: language acquisition in the classroom. Oxford: Pergamon Press.

[23] Larsen- Freeman, D. (2000). Techniques and principles in language teaching (2nd ed.). Oxford: Oxford University Press.

[24] Loewen, S. et al. (2009). Second language learners' beliefs about grammar instruction and error correction. The Modern Language Journal 93.1, 91-104.

[25] Matsuura, H., Chiba, R., \& P. Hilderbrandt. (2001). Beliefs about learning and teaching communicative English in Japan. Japan Association for Language Teaching 23 .1, 69-82.

[26] Miles, R. (2002). Employment and unemployment in Jordan: Importance of the gender system. World Development 30.3, 413427.

[27] Mourtaga, K. R. (2006). Some reading problems of Arab EFL students. Journal of Al-Aqsa University 10.2, 75-91.

[28] Newman, M. L., Groom, C. J., Handelman, L. D., \& J. W. Pennebaker. (2008). Gender differences in language use: An analysis of 14,000 text samples. Discourse Processes 45,211-236.

[29] Nunan, D. (1991). Communicative tasks and the language curriculum. TESOL Quarterly 25.2, 279-295.

[30] Prabhu, N.S. (1987). Second language pedagogy. Oxford: Oxford University Press.

[31] Rao, Z. (2002). Chinese university students' perceptions of communicative and non-communicative activities in EFL classroom. System 30, 85-105.

[32] Richards, J. (2006). Communicative language teaching today. Cambridge: Cambridge University Press.

[33] Richards, J., \& T. Rogers (1986). Approaches and methods in language teaching. Cambridge: Cambridge University Press.

[34] Sakui, K. \& Gaies, S. (1999). Investigating Japanese learners' beliefs about language learning. System 27, 473-492.

[35] Savignon, S. J. (1991). Communicative language teaching: State of the art. TESOL Quarterly 25.2, 261-277. 
[36] Savignon, S. J. (2007). Beyond communicative language teaching: What's ahead? Journal of Pragmatics 39, $207-220$.

[37] Savignon, S. J. \& C. Wang (2003). Communicative language teaching in EFL contexts: Learner attitudes and perceptions. IRAL 41, 223-249.

[38] Siebert, L. (2003). Student and teacher beliefs about language learning. The ORTESOL Journal 21, 7-39.

[39] Sunderland, J. (1992). Gender in the EFL classroom. ELT Journal 46, 81-91.

[40] Williams, J. (1995). Focus on form in communicative language teaching: research findings and the classroom teacher. TESOL Journal 4.4, 12-16.

[41] Willing, K. (1988). Learning Styles in Adult migrant Education. Adelaide: NCRC.

[42] Yi, F. (n. d.). Plateau of EFL Learning: A Psycholinguistic and Pedagogical Study. wlkc.nbu.edu.cn/jpkc_nbu/daxueyingyu/download/014.pdf (accessed 12/2/2011).

[43] Xin, X. (2008). On gender differences in language acquisition. Sino-US English Teaching 5, 6-10.

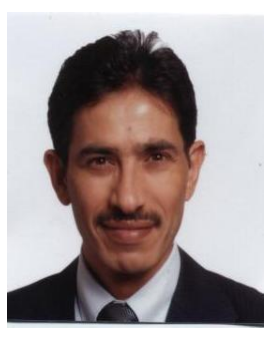

Sahail M. Asassfeh holds a B. A in English Language and Literature, a High Diploma in Education, a Master's degree, and a $\mathrm{PhD}$ in applied linguistics. He taught English at public and private basic and secondary schools for several years. He also worked for six years as a pre-service-training supervisor of English. Dr. Asassfeh is currently a Joint Assistant Professor of English \& Curriculum and Instruction at the Hashemite University, Jordan. E-mail: suahil_habashneh@yahoo.com

Faisal M. Khwaileh graduated from Yarmouk University, Jordan in 1982 with a B. A in English Language and Literature and a High Diploma degree in Teaching English as a Foreign Language. Dr. Khwaileh worked as a teacher of English language at secondary schools for several years then as a supervisor of English. In 1991, he earned a Master's degree in Teaching English as a Foreign Language (TEFL) from Yarmouk University, and then a Ph. D. degree in Curriculum, Teaching and Educational Policy from Michigan State University, USA, in 1998. Dr. Khwaileh is currently an Associate Professor of Curriculum and Instruction; he teaches courses at both the undergraduate and graduate programs in the Department of Curriculum and Instruction at the University of Jord an in Amman, Jordan. E-mail: khwaileh@ju.edu.jo

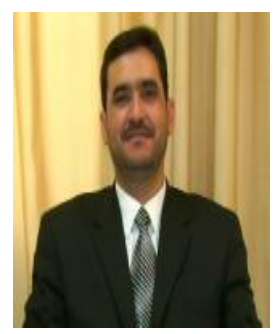

Yousef M. Al-Shaboul, born in a village to the north of Jordan, holds his $\mathrm{PhD}$ in Reading from University of North Texas, Denton, Texas in 2004. He worked in the Jordanian public schools as teacher of English language for 6 years before traveling to the United States to get his Ph.D. Upon receiving his Diploma, he taught at Midwestern State University, Wichita Fall, for one year as a Visiting professor. Now, he is an assistant professor at College of Education (Department of Curriculum \& Instruction and College of Art (Department of English) at The Hashemite University--Jordan. His areas of interest are reading, assessment, EFL, and family literacy. Dr. Al-Shaboul is a member in APETAU. He is on the team of Queen Rania Award for Distinguished Teacher for the second year. He has many publications in different areas of interests. E-mail: yshbool@hu.edu.jo

Sabri S. Alshboul was born in Jordan on the $1^{\text {st }}$ of October 1972. He obtained his Ph.D degree in Linguistics from the University of Kansas, USA. He worked as a teaching assistant in the department of English language and literature, the Hashemite University in Jordan between 2000-2003 and in the department of African, African, and American studies as a teaching assistant between 2005 2007. He is doing research on the investigation of language parameters and principles concerning English and Arabic with the children whose first language is Arabic. Dr. Alshboul participated in many conferences (CIBER conference, Ohio State University, USA, 2006; APETAU Conference, Tafila Technical Univiersity, Jordan, 2008; South Eastern Conference, The University of Mississippi, USA, 2010; The 20 $0^{\text {th }}$ Linguistic Days in Prague, The Metropolitan University, Czech Republic, 2011). He got a scholarship to pursue his PhD degree from the Hashemite University in the period 2003-2007. Email: sabri @ hu.edu.jo 